\title{
Chronic Spontaneous Urticaria: A Survey of 852 Cases of Childhood-Onset Systemic Lupus Erythematosus
}

\author{
Mariana Paes Leme Ferriani ${ }^{a}$ b $\quad$ Marco Felipe Castro Silva ${ }^{a}$ \\ Rosa Maria Rodrigues Pereira ${ }^{c}$ Maria Teresa Terreri ${ }^{d} \quad$ Claudia Saad Magalhães $^{e}$ \\ Eloisa Bonfác Antônio C. Pastorino ${ }^{b}$ Maria Carolina dos Santos ${ }^{f}$ \\ Simone Appenzeller ${ }^{g}$ Virginia Paes Leme Ferriani ${ }^{\text {h }}$ Claudio Arnaldo Len ${ }^{d}$ \\ Adriana Maluf Elias Sallum ${ }^{\mathrm{a}}$ Jonatas Libório ${ }^{\mathrm{i}}$ Tânia Caroline Monteiro de Castro $^{\mathrm{j}}$ \\ Clovis Artur Silva ${ }^{a}$ \\ Units of a Pediatric Rheumatology and bediatric Allergy and Immunology and ' Division of Rheumatology, Faculdade \\ de Medicina da Universidade de São Paulo (FMUSP), dPediatric Rheumatology Unit, Universidade Federal de São \\ Paulo (UNIFESP), e Faculdade de Medicina de Botucatu, São Paulo State University (UNESP), firmandade da Santa Casa

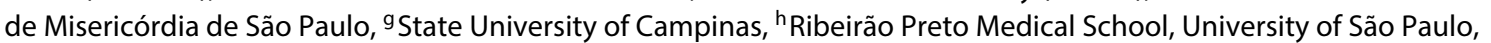 \\ 'Hospital Infantil Darcy Vargas, and ${ }^{\dagger}$ Hospital Municipal Infantil Menino Jesus, São Paulo, Brazil
}

\section{Key Words}

Childhood-onset systemic lupus erythematosus · Chronic spontaneous urticaria · Organ involvement

\footnotetext{
Abstract

Background: Data regarding the prevalence of chronic spontaneous urticaria (CSU) in childhood-onset systemic lupus erythematosus (CSLE) patients and possible associated factors are limited to a few case reports. The objectives of this study were to assess CSU in a large cSLE population, in order to evaluate the demographic data, clinical manifestations, disease activity/damage, laboratory abnormalities and treatment. Methods: A retrospective multicenter cohort study (Brazilian cSLE group) was performed in 10 Pediatric Rheumatology services and included 852 cSLE patients. CSU was diagnosed according to the guidelines of the European Academy of Allergy and Clinical Immunology, the Global Allergy and Asthma European Network, the European Derma-
}

tology Forum and the World Allergy Organization. Patients with CSU (evaluated at urticaria diagnosis) and patients without CSU (evaluated at the last visit) were assessed for lupus clinical/laboratory features and treatment. Results: CSU was observed in 10/852 cSLE patients (1.17\%). The median of cSLE duration at urticaria diagnosis was 0 (-3 to 5) years. Comparison of CSLE patients with and without CSU revealed a greater frequency of constitutional symptoms (40 vs. $8 \%, p=0.006)$, reticuloendothelial system involvement ( 30 vs. $3 \%, p=0.003$ ), mucocutaneous (90 vs. $28 \%, p<0.0001$ ) and musculoskeletal manifestations (50 vs. $6 \%, p<0.0001$ ) and methylprednisolone pulse therapy use (60 vs. $9 \%, p<$ 0.0001 ) in the former group. The frequency of immunosuppressive treatment was lower in patients with CSU ( $p=$ 0.018). The median SLE Disease Activity Index 2000 (12 vs. 2, $p<0.0001$ ) and erythrocyte sedimentation rate (40 vs. 19 $\mathrm{mm} / 1$ st hour, $\mathrm{p}=0.024$ ), was higher in patients with CSU. Conclusions: To our knowledge, this is the first study with evidence that CSU may be linked to CSLE. We also demon-

\section{KARGER 125}

(c) 2015 S. Karger AG, Base

$1018-2438 / 15 / 1673-0186 \$ 39.50 / 0$ 
strated that this particular skin manifestation occurs predominantly at disease onset and is associated with lupus moderate/high disease activity without major organ involvement.

(c) 2015 S. Karger AG, Basel

\section{Introduction}

Childhood-onset systemic lupus erythematosus (cSLE) is a rare autoimmune disorder that may affect multiple organs and systems $[1,2]$. The mucocutaneous involvement has been reported in approximately $70 \%$ of these patients $[1,3,4]$.

Indeed, a variety of cutaneous manifestations can be observed in lupus patients $[1,3,4]$, including urticaria [5-8]. This skin involvement is defined by the sudden onset of wheals, angioedema or both. Wheals are characterized by evanescent lesions, with central swelling of variable size usually surrounded by a reflex erythema, and associated with an itching or burning sensation [9].

A previous study found that patients with chronic urticaria have a higher incidence of SLE in the adult population, but a systematic evaluation of disease parameters was not performed [5]. Few case reports have evaluated urticaria either in adult cSLE patients [6-8]. However, the prevalence of this manifestation in the pediatric lupus population and the possible associated factors have not been studied.

Therefore, the objective of this study was to assess chronic spontaneous urticaria (CSU) in a large cSLE population, and to evaluate demographic data, clinical manifestations, disease activity, cumulative disease damage, laboratory abnormalities and treatment.

\section{Materials and Methods}

\section{Study Procedure and Patient Selection}

This was a retrospective, multicenter cohort study (Brazilian cSLE group) including 1,017 cSLE patients followed in 10 Pediatric Rheumatology tertiary referral services in São Paulo State, Brazil. One hundred and sixty-five patients were excluded due to incomplete medical charts $(\mathrm{n}=96)$, undifferentiated connective tissue disorder with $\leq 3$ American College of Rheumatology (ACR) criteria $(n=43)$, isolated cutaneous lupus erythematosus $(n=11)$, neonatal lupus erythematosus $(\mathrm{n}=8)$, drug-induced lupus $(\mathrm{n}=5)$ and other autoimmune diseases $(n=2)$. None of the patients had urticaria vasculitis, hypocomplementemic urticaria vasculitis syndrome or malignancies. Therefore, the study group comprised 852 cSLE patients. All patients fulfilled the ACR lupus criteria [10], with disease onset before 18 years of age [11] and current age of $\leq 25$ years. The Committee for Research Ethics of each center approved the study.
An investigator meeting was held for this study on the 29 September 2012 in São Paulo city to define the protocol and standardize clinical, laboratory and treatment parameters definition, disease activity and damage-tools scoring. Data collection training was conducted locally by investigators in each center and a unique database was built up (by M.P.L.F. and M.F.C.S.). Data discrepancy was sorted out by $\geq 1$ rounds of queries for accuracy. Data were collected between November 2012 and October 2014.

Patient's medical charts were carefully reviewed according to an extensive standardized protocol for demographic data, clinical features, laboratory findings, therapeutic data, outcomes and CSU characteristics. Patients with CSU (evaluated at urticaria diagnosis) and patients without CSU (evaluated at the last visit) were divided in 2 groups and assessed for the clinical, laboratory and treatment features of lupus.

CSU was diagnosed according to the dermatology section of the guidelines of the European Academy of Allergy and Clinical Immunology, the EU-funded Network of Excellence, the Global Allergy and Asthma European Network, the European Dermatology Forum and the World Allergy Organization, and defined as the spontaneous appearance of at least one manifestation, i.e. a wheal and/or angioedema that lasted for $\geq 6$ weeks, excluding inducible urticaria [9]. We evaluated the total urticaria duration (from onset of wheals to complete resolution), the time between urticaria onset and cSLE diagnosis, the distribution of wheals, the presence of angioedema, painful lesions, current allergies (rhinitis and asthma), a family history of atopic diseases and current infections. Eosinophilia $\left(>500\right.$ eosinophils $\left./ \mathrm{mm}^{3}\right)$ and elevated levels of serum $\operatorname{IgE}(>200 \mathrm{IU} / \mathrm{ml})$ were also evaluated.

\section{Demographic Data, Clinical Evaluation, Disease Activity and}

Damage and Therapies

Demographic data included gender, race, current age, age at cSLE onset and disease duration. SLE clinical manifestations were defined as: constitutional symptoms (fever and weight loss), involvement of the reticuloendothelial system (adenomegaly, hepatomegaly and splenomegaly), mucocutaneous lesions (malar or discoid rash, photosensitivity, nasal or oral ulcers, alopecia and cutaneous vasculitis, i.e. ulceration, periungueal infarction or splinter hemorrhage), musculoskeletal involvement (nonerosive arthritis and myositis), serositis (pleuritis and pericarditis), nephritis (proteinuria $\geq 0.5 \mathrm{~g} / 24 \mathrm{~h}$, the presence of cellular casts, persistent hematuria $\geq 5$ red blood cells/high-power field and/or persistent leukocituria $\geq 5$ leukocytes/high-power field), hematologic abnormalities, i.e. autoimmune hemolytic anemia, leukopenia (a white blood cell count $<4,000 / \mathrm{mm}^{3}$ ), lymphopenia (lymphocytes $<1,500 / \mathrm{mm}^{3}$ ) and thrombocytopenia (a platelet count $<100,000 /$ $\mathrm{mm}^{3}$ ) on two or more occasions in the absence of drugs or infection. Neuropsychiatric lupus included 19 syndromes according to ACR classification criteria [12]. Hypothyroidism was defined as reduced free thyroxine $\left(\mathrm{T}_{4}\right)$ and elevated thyroid-stimulating hormone (TSH) levels, and subclinical hypothyroidism as elevated $\mathrm{TSH}$ associated with normal $\mathrm{T}_{4}$. The presence of antithyroid antibodies, i.e. antithyroid peroxidase, antithyroglobulin and antiTSH receptor antibody, and hypothyroidism was necessary for a diagnosis of autoimmune thyroiditis [13]. Antiphospholipid syndrome was diagnosed according to the presence of arterial and/or venous thrombosis and antiphospholipid antibodies [14].

High blood pressure was defined as systolic and/or diastolic blood pressures $\geq 95$ th percentile for gender, age and height on $\geq 3$ 
Table 1. CSU characteristics in cSLE patients

\begin{tabular}{|c|c|c|c|c|c|c|c|c|c|c|}
\hline \multirow[t]{2}{*}{ Characteristics } & \multicolumn{10}{|c|}{ Patient No. } \\
\hline & 1 & 2 & 3 & 4 & 5 & 6 & 7 & 8 & 9 & 10 \\
\hline Age at CSU onset, years & 13.1 & 10.7 & 10.2 & 13.2 & 17.1 & 16.2 & 7.1 & 8.7 & 13.8 & 15.7 \\
\hline Disease duration until CSU, months & -36 & 0 & -6 & 7 & 1 & 0 & 0 & 0 & 61 & 0 \\
\hline Total duration of CSU, days & 65 & 60 & 272 & 270 & 140 & 240 & 720 & 140 & 44 & 760 \\
\hline Angioedema & yes & no & no & no & no & yes & no & no & no & yes \\
\hline Allergic asthma & yes & no & no & no & no & no & no & no & yes & no \\
\hline Allergic rhinitis & no & no & yes & no & no & yes & no & no & no & no \\
\hline Autoimmune thyroiditis & yes & no & no & no & no & no & yes & no & no & no \\
\hline Drug therapy & $\mathrm{CE}, \mathrm{AH}$ & $\mathrm{CE}, \mathrm{AH}$ & $\begin{array}{l}\mathrm{CE}, \mathrm{AH}, \\
\mathrm{AM}\end{array}$ & $\begin{array}{l}\mathrm{CE}, \mathrm{AH}, \\
\mathrm{AM}\end{array}$ & $\mathrm{CE}, \mathrm{AM}$ & $\begin{array}{l}\mathrm{CE}, \mathrm{AH}, \\
\mathrm{AM}\end{array}$ & $\begin{array}{l}\text { CE, AM, } \\
\text { Aza }\end{array}$ & $\mathrm{CE}, \mathrm{AM}$ & $\begin{array}{l}\text { CE, AM, } \\
\text { Mtx }\end{array}$ & $\begin{array}{l}\mathrm{CE}, \mathrm{AH}, \\
\mathrm{AM}\end{array}$ \\
\hline
\end{tabular}

$\mathrm{AH}=\mathrm{H} 1$-antihistamines $\mathrm{AM}=$ antimalarials; $\mathrm{Aza}=$ azathioprine $\mathrm{CE}=$ corticosteroids; $\mathrm{Mtx}=$ methotrexate.

occasions [15]. Acute kidney injury was determined by a sudden increase in serum creatinine $>2 \mathrm{mg} / \mathrm{dl}$ [16] or by modified RIFLE (risk, injury, failure, loss of kidney function and end-stage kidney disease) criteria [17]. Chronic renal disease was defined as structural or functional abnormalities of the kidney for $\geq 3$ months (with or without a decreased glomerular filtration rate) or a glomerular filtration rate $<60 \mathrm{ml} / \mathrm{min} / 1.73 \mathrm{~m}^{2}$ for $\geq 3$ months [18]

Laboratorial assessment included the erythrocyte sedimentation rate, C-reactive protein, a complete blood cell count, serum urea and creatinine, urinalysis and 24 -hour urine protein excretion. Complement levels (CH50, C3 and C4) and anti-doublestranded DNA autoantibodies were carried out at each of the centers involved and the cut off values were considered valid. SLE disease activity and cumulative damage were scored according to the SLE Disease Activity Index 2000 (SLEDAI-2K) [19], which may range from 0 to 105, and the Systemic Lupus International Collaborating Clinics/ACR-Damage Index [20], which may range from 0 to 47, respectively.

Current therapy (prednisone, intravenous methylprednisolone pulse, chloroquine diphosphate, hydroxychloroquine sulfate, methotrexate, azathioprine, cyclosporine, mycophenolate, intravenous cyclophosphamide, intravenous gammaglobulin and rituximab) was also recorded.

\section{Statistical Analysis}

Results are presented as number (\%) for categorical variables and median (range) for continuous variables. Comparisons of categorical variables were assessed by the Fisher exact test. Continuous variables from cSLE patients with and without CSU were compared with the Mann-Whitney test. The significance levels of the independent variables were set at $5 \%(\mathrm{p}<0.05)$.

\section{Results}

CSU was observed in 10/852 cSLE patients (1.17\%) with a median of total urticaria duration of 190 days (44-760 days). The median cSLE duration at urticaria diagnosis was
$0(-3$ to 5$)$ years and the age at urticaria onset was $13(7-17)$ years. Isolated CSU was observed in $2 \mathrm{cSLE}$ patients before lupus diagnosis, at diagnosis in 5 and after diagnosis in 3. Wheals were present in all of the 10 cSLE patients and angioedema was observed in 3 . Wheal distribution was diffuse (trunk, upper/lower limbs and/or face) in 9 and in the lower limbs in 1. None of them had painful lesions, acute/ chronic infections or helminthic parasitic infections. Current allergies were reported in 4/10 patients: rhinitis in 2 and asthma in 2. A family history of atopic diseases was observed in $3 / 10$ patients. Eosinophilia was evident in 1/10 with no allergy spectrum. IgE was available in 5/10 cSLE patients and an elevated serum IgE level was observed in $1 / 5$ cSLE patients without asthma or rhinitis. Moderate disease activity, at least (SLEDAI-2K $\geq 6$ ), was observed in $100 \%$. Medications used for CSU included H1-antihistamines and glucocorticoids for 2 patients who developed CSU before cSLE diagnosis. The other patients presenting with CSU at or after lupus diagnosis were treated with H1antihistamines (60\%), glucocorticoids (100\%), antimalarials $(80 \%)$ and immunosuppressive agents (20\%). Table 1 shows CSU characteristics in cSLE patients.

Demographic data, clinical manifestations and disease activity/damage scores in $852 \mathrm{cSLE}$ patients according to the presence of CSU are shown in table 2. The comparison of CSLE patients with and without CSU revealed greater frequency of constitutional symptoms ( $40 \mathrm{vs.} 8 \%$, $\mathrm{p}=0.006$ ), reticuloendothelial system involvement (30 vs. $3 \%, \mathrm{p}=0.003)$ and mucocutaneous (90 vs. $28 \%, \mathrm{p}<$ 0.0001 ) and musculoskeletal manifestations (50 vs. $6 \%$, $\mathrm{p}<0.0001)$. The median SLEDAI-2K (12 vs. $2, \mathrm{p}<0.0001)$ was also significantly greater in patients with CSU. Disease damage (current Systemic Lupus International Col- 
Table 2. Demographic data, clinical manifestations and disease activity/damage scores in 852 cSLE patients at CSU diagnosis compared to those without CSU (at last visit)

\begin{tabular}{|c|c|c|c|}
\hline Variables & $\begin{array}{l}\text { With CSU } \\
(\mathrm{n}=10)\end{array}$ & $\begin{array}{l}\text { Without CSU } \\
(\mathrm{n}=842)\end{array}$ & $\mathrm{p}$ value \\
\hline \multicolumn{4}{|l|}{ Demographic data } \\
\hline Female gender $(n=852)$ & $8 / 10(80)$ & $724 / 842(86)$ & 0.639 \\
\hline Caucasian $(\mathrm{n}=830)$ & $8 / 10(80)$ & $584 / 820(71)$ & 0.733 \\
\hline Age at cSLE onset, years $(n=846)$ & $11.62(7.1-17)$ & $11.87(0.25-17.83)$ & 0.554 \\
\hline \multicolumn{4}{|l|}{ Clinical manifestations } \\
\hline Constitutional features $(\mathrm{n}=848)$ & $4 / 10(40)$ & $64 / 838(8)$ & 0.006 \\
\hline Fever $(n=848)$ & $2 / 10(20)$ & $47 / 838(6)$ & 0.109 \\
\hline Weight loss $(n=823)$ & $3 / 10(30)$ & $27 / 813(3)$ & 0.004 \\
\hline Reticuloendothelial system involvement $(\mathrm{n}=848)$ & $3 / 10(30)$ & $23 / 838(3)$ & 0.003 \\
\hline Lymphadenopathy $(\mathrm{n}=847)$ & $2 / 10(20)$ & $11 / 837(1)$ & 0.009 \\
\hline Hepatomegaly $(n=848)$ & $1 / 10(10)$ & $17 / 838(2)$ & 0.194 \\
\hline Splenomegaly $(\mathrm{n}=848)$ & $0 / 10(0)$ & $6 / 838(1)$ & 1.000 \\
\hline Mucocutaneous involvement $(\mathrm{n}=850)$ & $9 / 10(90)$ & $239 / 840(28)$ & $<0.0001$ \\
\hline Malar rash $(\mathrm{n}=847)$ & $6 / 10(60)$ & $114 / 837(14)$ & 0.001 \\
\hline Discoid rash $(\mathrm{n}=849)$ & $0 / 10(0)$ & $12 / 839(1)$ & 1.000 \\
\hline Photosensitivity $(\mathrm{n}=850)$ & $8 / 10(80)$ & $107 / 840(13)$ & $<0.0001$ \\
\hline Mucosal ulcers $(\mathrm{n}=849)$ & $1 / 10(10)$ & $35 / 839(4)$ & 0.353 \\
\hline Alopecia $(\mathrm{n}=849)$ & $4 / 10(40)$ & $63 / 839(7)$ & 0.005 \\
\hline Cutaneous vasculitis $(\mathrm{n}=848)$ & $4 / 10(40)$ & $52 / 838(6)$ & 0.003 \\
\hline Musculoskeletal involvement $(\mathrm{n}=850)$ & $5 / 10(50)$ & $52 / 840(6)$ & $<0.0001$ \\
\hline Arthritis $(\mathrm{n}=849)$ & $4 / 10(40)$ & $47 / 839(6)$ & 0.002 \\
\hline Myositis $(\mathrm{n}=849)$ & $1 / 10(10)$ & $6 / 839(1)$ & 0.080 \\
\hline Serositis $(n=850)$ & $0 / 10(0)$ & $13 / 840(1)$ & 1.000 \\
\hline Pleuritis $(\mathrm{n}=848)$ & $0 / 10(0)$ & $11 / 838(1)$ & 1.000 \\
\hline Pericarditis $(\mathrm{n}=848)$ & $0 / 10(0)$ & $11 / 838(1)$ & 1.000 \\
\hline Neuropsychiatric involvement $(\mathrm{n}=850)$ & $1 / 10(10)$ & $68 / 840(8)$ & 0.573 \\
\hline Central nervous system $(\mathrm{n}=847)$ & $1 / 10(10)$ & $67 / 837(8)$ & 0.569 \\
\hline Peripheral nervous system $(\mathrm{n}=844)$ & $0 / 10(0)$ & $4 / 834(0)$ & 1.000 \\
\hline Nephritis $(n=830)$ & $3 / 10(30)$ & $165 / 820(20)$ & 0.432 \\
\hline \multicolumn{4}{|l|}{ Other } \\
\hline Arterial hypertension $(n=842)$ & $1 / 10(10)$ & $108 / 832(13)$ & 1.000 \\
\hline Acute renal failure $(\mathrm{n}=841)$ & $0 / 10(0)$ & $31 / 831(4)$ & 1.000 \\
\hline Chronic renal failure $(\mathrm{n}=841)$ & $0 / 10(0)$ & $25 / 831(3)$ & 1.000 \\
\hline \multicolumn{4}{|l|}{ Disease activity/damage } \\
\hline SLEDAI-2K $(\mathrm{n}=753)$ & $12(4-24)$ & $2(0-45)$ & $<0.0001$ \\
\hline SLICC/ACR-DI $(\mathrm{n}=770)$ & $0(0-1)$ & $0(0-9)$ & 0.740 \\
\hline
\end{tabular}

Results are presented as $\mathrm{n}(\%)$ or median (range). SLICC/ACR-DI = Systemic Lupus International Collaborating Clinics/ACR - Damage Index.

laborating Clinics/ACR-Damage Index value) was similar in the 2 groups ( $\mathrm{p}=0.740$; table 2$)$.

Laboratory characteristics and treatment of $852 \mathrm{cSLE}$ according to the presence of CSU are illustrated in table 3. The median erythrocyte sedimentation rate (40 vs. 19 $\mathrm{mm} / 1$ st hour, $\mathrm{p}=0.024)$ and current prednisone dose in $\mathrm{mg} /$ day (30 vs. $11.2, \mathrm{p}=0.010)$ and in $\mathrm{mg} / \mathrm{kg} /$ day (0.89 vs. $0.22, \mathrm{p}<0.0001)$ were significantly higher in patients with CSU than in without urticaria. The use of methylpred- nisolone pulse therapy (60 vs. $9 \%, \mathrm{p}<0.0001$ ) was significantly greater in the former group. The frequency of immunosuppressive treatment was lower in patients with CSU (20 vs. $61 \%, \mathrm{p}=0.018$; table 3 ).

Further analysis of associated diseases demonstrated that autoimmune thyroiditis was evident in $2 / 10$ of CSU cSLE patients (20\%) compared to 30/806 without CSU $(4 \%, \mathrm{p}=0.055)$. No case of antiphospholipid syndrome was observed in the former group ( 0 vs. $5 \%, \mathrm{p}=1.0$ ). 
Table 3. Laboratory characteristics and treatment of $852 \mathrm{cSLE}$ patients at CSU diagnosis compared to the patients without CSU (at the last visit)

\begin{tabular}{|c|c|c|c|}
\hline Variables & $\begin{array}{l}\text { With CSU } \\
(\mathrm{n}=10)\end{array}$ & $\begin{array}{l}\text { Without CSU } \\
(\mathrm{n}=842)\end{array}$ & $\mathrm{p}$ value \\
\hline \multicolumn{4}{|l|}{ Laboratory values } \\
\hline ESR, mm/1st hour, $(\mathrm{n}=709)$ & $40(15-95)$ & $19(1-135)$ & 0.024 \\
\hline $\mathrm{CRP}, \mathrm{mg} / \mathrm{dl}(\mathrm{n}=551)$ & $1.79(0-14)$ & $0.7(0-404)$ & 0.320 \\
\hline Autoimmune hemolytic anemia $(\mathrm{n}=825)$ & $0 / 10(0)$ & $26 / 815(3)$ & 1.000 \\
\hline Leukopenia $<4,000 / \mathrm{mm}^{3}(\mathrm{n}=788)$ & $1 / 10(10)$ & $62 / 778(8)$ & 0.568 \\
\hline Lymphopenia $<1,500 / \mathrm{mm}^{3}(\mathrm{n}=788)$ & $3 / 10(30)$ & $138 / 778(18)$ & 0.396 \\
\hline Thrombocytopenia, $<150,000 / \mathrm{mm}^{3}(\mathrm{n}=793)$ & $0 / 10(0)$ & $37 / 783(5)$ & 1.000 \\
\hline Hematuria $(n=755)$ & $3 / 10(30)$ & $133 / 745(18)$ & 0.398 \\
\hline Cilindruria $(\mathrm{n}=746)$ & $0 / 10(0)$ & $27 / 736(4)$ & 1.000 \\
\hline Proteinuria $(n=641)$ & $1 / 10(10)$ & $149 / 631(24)$ & 0.466 \\
\hline Low C3, C4 and/or CH50 $(\mathrm{n}=617)$ & $5 / 8(62)$ & $271 / 609(44)$ & 0.477 \\
\hline Anti-double-stranded DNA $(\mathrm{n}=718)$ & $3 / 10(30)$ & $265 / 708(37)$ & 0.751 \\
\hline \multicolumn{4}{|l|}{ Treatment } \\
\hline Nonsteroidal anti-inflammatory drugs $(\mathrm{n}=840)$ & $0 / 10(0)$ & $46 / 830(5)$ & 1.000 \\
\hline \multicolumn{4}{|l|}{ Glucocorticosteroids } \\
\hline Prednisone $(\mathrm{n}=842)$ & $10 / 10(100)$ & $655 / 832(79)$ & 0.132 \\
\hline Current dose, mg/day $(n=665)$ & $30(1-60)$ & $11.2(1-90)$ & 0.010 \\
\hline $\mathrm{mg} / \mathrm{kg} /$ day $(\mathrm{n}=644)$ & $0.89(0.35-1.2)$ & $0.22(0.02-10)$ & $<0.0001$ \\
\hline Methylprednisolone pulse therapy $(\mathrm{n}=838)$ & $6 / 10(60)$ & $71 / 828(9)$ & $<0.0001$ \\
\hline Antimalarial drugs $(n=839)$ & $8 / 10(80)$ & $558 / 829(67)$ & 0.513 \\
\hline Chloroquine diphosphate $(\mathrm{n}=814)$ & $2 / 10(20)$ & $129 / 804(16)$ & 0.667 \\
\hline Hydroxychloroquine sulfate $(\mathrm{n}=816)$ & $6 / 10(60)$ & $444 / 806(55)$ & 1.000 \\
\hline Immunosuppressive agents $(\mathrm{n}=843)$ & $2 / 10(20)$ & $505 / 833(61)$ & 0.018 \\
\hline Azathioprine $(\mathrm{n}=840)$ & $1 / 10(10)$ & $287 / 830(35)$ & 0.178 \\
\hline Cyclosporine $(\mathrm{n}=843)$ & $0 / 10(0)$ & $30 / 833(4)$ & 1.000 \\
\hline Methotrexate $(\mathrm{n}=842)$ & $1 / 10(10)$ & $70 / 832(8)$ & 0.588 \\
\hline Mycophenolate mofetil $(\mathrm{n}=843)$ & $0 / 10(0)$ & $117 / 833(14)$ & 0.373 \\
\hline Cyclophosphamide $(\mathrm{n}=842)$ & $0 / 10(0)$ & $45 / 832(5)$ & 1.000 \\
\hline \multicolumn{4}{|l|}{ Other } \\
\hline Intravenous immunoglobulin $(\mathrm{n}=842)$ & $0 / 10(0)$ & $14 / 832(2)$ & 1.000 \\
\hline Rituximab $(n=841)$ & $0 / 10(0)$ & $1 / 831(0)$ & 1.000 \\
\hline
\end{tabular}

Results are presented as $\mathrm{n}(\%)$ or median (range). CRP = C-reactive protein; ESR = erythrocyte sedimentation rate.

\section{Discussion}

To our knowledge, this is the first study with evidence that CSU may be linked to CSLE patients and associated with moderate/high disease activity.

The strength of this multicentric study was the large sample size of the cSLE population followed at 10 university services in São Paulo State, Brazil, as well as the use of a standardized database to minimize bias. The CSU definition was based on international consensus [9]. Diseases related to urticaria/angioedema were excluded, particularly urticaria vasculitis and hypocomplementemic urticaria vasculitis syndrome [21-23], since these abnor- malities are associated with localized, nonblanching, painful lesions [23] which persist for $>24 \mathrm{~h}$ and leave brownish residues when healed [22].

The main weakness of the study was the retrospective design with possible missing data. An evaluation of autoimmune markers associated with CSU, such as an autologous serum skin test or circulating functional autoantibodies (directed against IgE or high-affinity IgE receptor - FceRI), was not performed [24-27], and an IgE measurement was not available for all patients with CSU. Cryopyrin-associated periodic syndromes and hereditary or acquired $\mathrm{C} 1$ esterase inhibitor deficiency were also not systematically evaluated. 
Other autoimmune disorders have been associated with CSU, including dermatomyositis, polymyositis, Sjögren syndrome and juvenile idiopathic arthritis [28]. We describe a low frequency of CSU in a large population of cSLE patients. Of note, the majority of cSLE patients presented this skin manifestation before or at disease onset, as was also observed previously in case reports of adult and cSLE patients $[6,8]$.

Interestingly, our study indicated that CSU may be linked to active CSLE, with a predominance of constitutional, mucocutaneous and musculoskeletal involvement, without a high frequency of severe lupus manifestations.

We also evaluated antithyroid antibodies, which are the most common autoantibodies reported in adults (14$33 \%)$ and children $(4.3 \%)$ with chronic urticaria [5, 24, 29-32]. Twenty percent of the cSLE patients with CSU evaluated had autoimmune thyroid disease; this contrasts with the $7 \%$ of this endocrine abnormality previously reported in a cohort study regarding the overall cSLE population at a single center [13]. The pathophysiology of this disorder is unknown, but the immune dysregulation may be related to autoimmunity or to chronic inflammatory processes [5].

The frequency of CSU in cSLE is within the expected range reported in other populations of children and adolescents $(0.1-3 \%)[31,33]$. There are, however, no systematic studies regarding the prevalence of CSU in the Brazilian pediatric population. In addition, the analysis of the influence of race was hampered by the small representation of non-Caucasian patients in our sample.

CSU may be triggered by lupus treatment medications, particularly nonsteroidal anti-inflammatory drugs $[9,28$, 29], but none of our patients was under this therapy at CSU onset. The majority of cSLE patients were treated with $\mathrm{H} 1$-antihistamines, according to the literature recommendations [28, 29]. Moderate glucocorticoid dose and/or intravenous methylprednisolone pulse were required to treat our lupus patients with CSU and the majority did not need immunosuppressive agents.
In conclusion, urticaria was linked to early cSLE. We also demonstrated that this skin manifestation is associated with lupus moderate/high disease activity without major organ involvement.

\section{Acknowledgements}

Our gratitude to Ulysses Doria-Filho for the statistical analysis. The authors thank the following Pediatric Rheumatology Divisions and colleagues for including their patients: Pediatric Rheumatology Unit, FMUSP (Cristina Miuki Abe Jacob, Gabriela Blay, Gabriela Nunes Leal, Gabriella Erlacher Lube de Almeida, Heloisa Helena de Souza Marques, João Domingos Montoni da Silva, Joaquim Carlos Rodrigues, Juliana Caíres de Oliveira Achili Ferreira, Kátia Kozu, Laila Pinto Coelho, Lucia Maria Mattei Arruda Campos, Luciana dos Santos Henriques, Magda Carneiro-Sampaio, Maria Helena Vaisbich, Nadia Emi Aikawa, Roberta Cunha Gomes, Victor Leonardo Saraiva Marques and Werther Brunow de Carvalho), Pediatric Rheumatology Unit, UNIFESP (Ana Paula Sakamoto, Anandreia Simões Lopes, Daniela Petry Piotto, Giampaolo Faquin, Gleice Clemente, Maria Odete Esteves Hilário, Melissa Fraga, Octavio Augusto Bedin Peracchi and Vanessa Bugni), Division of Rheumatology, FMUSP (Juliane A. Paupitz), UNESP (Priscila R. Aoki, Juliana de Oliveira Sato, Silvana Paula Cardin and Taciana Albuquerque Pedrosa Fernandes), Irmandade da Santa Casa de Misericórdia de São Paulo (Andressa Guariento, Eunice Mitiko Okuda, Natali Weniger Spelling Gormenzano and Silvana Brasília Sacchetti), State University of Campinas (Marisa Centeville, Renata Barbosa and Roberto Marini), Ribeirão Preto Medical School, University of São Paulo (Francisco Hugo Gomes, Gecilmara Salviatto Pileggi, Luciana Martins de Carvalho and Paola Pontes Pinheiro), Hospital Infantil Darcy Vargas (Cássia Maria Passarelli Lupoli Barbosa and Luciana Tudech Pedro Paulo), Pontifical Catholic University of Sorocaba (Valeria Cristina Santucci Ramos) and Hospital Municipal Infantil Menino Jesus (Simone Lotufo). The study was sponsored by grants from the Conselho Nacional de Desenvolvimento Científico e Tecnológico to R.M.R.P. (CNPq 301805/2013-0), E.B. (2009/51897-5) and C.A.S. (302724/2011-7), the Federico Foundation (to R.M.R.P., E.B. and C.A.S.,) and the Núcleo de Apoio à Pesquisa 'Saúde da Criança e do Adolescente' da USP (NAP-CriAd) to C.A.S.

\section{Disclosure Statement}

The authors have no conflict of interest that is directly relevant to the content of this manuscript.

\section{References}

1 Faco MM, Leone C, Campos LM, Febrônio MV, Marques HH, Silva CA: Risk factors associated with the death of patients hospitalized for juvenile systemic lupus erythematosus. Braz J Med Biol Res 2007;40:993-1002.

2 Brunner HI, Huggins J, Klein-Gitelman MS: Pediatric SLE - towards a comprehensive management plan. Nat Rev Rheumatol 2011; 7:225-233.

3 Chiewchengchol D, Murphy R, Morgan T, Edwards SW, Leone V, Friswell M, Pilkington C, Tullus K, Rangaraj S, McDonagh JE, Gardner-Medwin J, Wilkinson N, Riley P, Tizard J, Armon K, Sinha MD, Ioannou
Y, Mann R, Bailey K, Davidson J, Baildam EM, Pain CE, Cleary G, McCann LJ, Beresford MW: Mucocutaneous manifestations in a UK national cohort of juvenileonset systemic lupus erythematosus patients. Rheumatology (Oxford) 2014;53: 1504-1512. 
4 Lourenço DM, Cunha Gomes R, Aikawa NE, Campos LM, Romiti R, Silva CA: Childhoodonset bullous systemic lupus erythematosus. Lupus 2014;23:1422-1425.

5 Confino-Cohen R, Chodick G, Shalev V, Leshno M, Kimhi O, Goldberg A: Chronic urticaria and autoimmunity: associations found in a large population study. J Allergy Clin Immunol 2012;129:1307-1313.

6 Spadoni M, Jacob C, Aikawa N, Jesus A, Fomin A, Silva C: Chronic autoimmune urticaria as the first manifestation of juvenile systemic lupus erythematosus. Lupus 2011;20:763766.

7 Yell JA, Mbuagbaw J, Burge SM: Cutaneous manifestations of systemic lupus erythematosus. Br J Dermatol 1996;135:355-362.

8 Kutlu A, Oztürk S, Onem Y, Nalbant S, Kiralp MZ, Taskapan O, Ozçakar L: Simple urticaria and systemic lupus erythematosus: why they wait? Lupus 2010;19:334.

9 Zuberbier T, Aberer W, Asero R, BindslevJensen C, Brzoza Z, Canonica GW, Church MK, Ensina LF, Giménez-Arnau A, Godse K Gonçalo M, Grattan C, Hebert J, Hide M, Kaplan A, Kapp A, Abdul Latiff AH, MathelierFusade P, Metz M, Nast A, Saini SS, SánchezBorges M, Schmid-Grendelmeier P, Simons FE, Staubach P, Sussman G, Toubi E, Vena GA, Wedi B, Zhu XJ, Maurer M: The EAACI/ $\mathrm{GA}^{2} \mathrm{LEN} / \mathrm{EDF} / \mathrm{WAO}$ guideline for the definition, classification, diagnosis, and management of urticaria: the 2013 revision and update. Allergy 2014;69:868-887.

10 Hochberg MC: Updating the American College of Rheumatology revised criteria for the classification of systemic lupus erythematosus. Arthritis Rheum 1997;40:1725.

11 Silva CA, Avcin T, Brunner HI: Taxonomy for systemic lupus erythematosus with onset before adulthood. Arthritis Care Res (Hoboken) 2012;64:1787-1793.

12 American College of Rheumatology ad hoc Committee on Neuropsychiatric Lupus Syndromes: The American College of Rheumatology nomenclature and case definitions for neuropsychiatric lupus syndromes. Arthritis Rheum 1999;42:599-608

13 Aikawa NE, Jesus AA, Liphaus BL, Silva CA, Carneiro-Sampaio M, Viana VS, Sallum AM: Organ-specific autoantibodies and autoim- mune diseases in juvenile systemic lupus erythematosus and juvenile dermatomyositis patients. Clin Exp Rheumatol 2012;30:126-131.

14 Avcin T, Cimaz R, Rozman B: The Ped-APS Registry: the antiphospholipid syndrome in childhood. Lupus 2009;18:894-899.

15 National High Blood Pressure Education Program Working Group on High Blood Pressure in Children and Adolescents: The fourth report on the diagnosis, evaluation, and treatment of high blood pressure in children and adolescents. Pediatrics 2004;114:555-576.

16 Chan JC, Williams DM, Roth KS: Kidney failure in infants and children. Pediatr Rev 2002; 23:47-60.

17 Akcan-Arikan A, Zappitelli M, Loftis LL, Washburn KK, Jefferson LS, Goldstein SL: Modified RIFLE criteria in critically ill children with acute kidney injury. Kidney Int 2007;71:1028-1035.

18 National Kidney Foundation: K/DOQI clinical practice guidelines for chronic kidney disease: evaluation, classification, and stratification. Am J Kidney Dis 2002;39:S1-S266

19 Gladman DD, Ibañez D, Urowitz MB: Systemic lupus erythematosus disease activity index 2000. J Rheumatol 2002;29:288-291.

20 Gladman DD, Goldsmith CH, Urowitz MB, Bacon P, Fortin P, Ginzler E, Gordon C, Hanly JG, Isenberg DA, Petri M, Nived O, Snaith M, Sturfelt G: The development and initial validation of the Systemic Lupus International Collaborating Clinics/American College of Rheumatology damage index for systemic lupus erythematosus. Arthritis Rheum 1996;39: 363-369.

21 Moreno-Suárez F, Pulpillo-Ruiz Á, Zulueta Dorado T, Conejo-Mir Sánchez J: Urticarial vasculitis: a retrospective study of 15 cases. Actas Dermosifiliogr 2013;104:579-585.

22 Roy K, Talukdar A, Kumar B, Sarkar S: Hypocomplementaemic urticarial vasculitis syndrome: a mimicker of systemic lupus erythematosus. BMJ Case Rep 2013;22:2013.

23 DeAmicis T, Mofid MZ, Cohen B, Nousari HC: Hypocomplementemic urticarial vasculitis: report of a 12 -year-old girl with systemic lupus erythematosus. J Am Acad Dermatol 2002;47:S273-S274.

24 Yadav S, Kanwar A, Parsad D, Minz R: Chronic idiopathic urticaria and thyroid au- toimmunity: perplexing association. Indian J Dermatol 2013;58:325

25 Du Toit G, Prescott R, Lawrence P, Johar A, Brown G, Weinberg EG, Motala C, Potter PC: Autoantibodies to the high-affinity IgE receptor in children with chronic urticaria. Ann Allergy Asthma Immunol 2006;96:341344.

26 Brunetti L, Francavilla R, Miniello VL, Platzer MH, Rizzi D, Lospalluti ML, Poulsen LK, Armenio L, Skov PS: High prevalence of autoimmune urticaria in children with chronic urticaria. J Allergy Clin Immunol 2004;114:922927.

27 Cho CB, Stutes SA, Altrich ML, Ardoin SP, Phillips G, Ogbogu PU: Autoantibodies in chronic idiopathic urticaria and nonurticarial systemic autoimmune disorders. Ann Allergy Asthma Immunol 2013;110:29-33.

28 Bernstein JA, Lang DM, Khan DA, Craig T, Dreyfus D, Hsieh F, Sheikh J, Weldon D, Zuraw B, Bernstein DI, Blessing-Moore J, Cox L, Nicklas RA, Oppenheimer J, Portnoy JM, Randolph CR, Schuller DE, Spector SL, Tilles SA, Wallace D: The diagnosis and management of acute and chronic urticaria: 2014 update. J Allergy Clin Immunol 2014;133:12701277.

29 Bailey E, Shaker M: An update on childhood urticaria and angioedema. Curr Opin Pediatr 2008;20:425-430.

30 Irani C, Jammal M, Asmar G, Hajj H, Halaby G: Chronic urticaria and autoimmune thyroiditis. J Med Liban 2012;60:88-90.

31 Sahiner UM, Civelek E, Tuncer A, Yavuz ST, Karabulut E, Sackesen C, Sekerel BE: Chronic urticaria: etiology and natural course in children. Int Arch Allergy Immunol 2011;156: 224-30.

32 Rabelo-Filardi R, Daltro-Oliveira R, Campos RA: Parameters associated with chronic spontaneous urticaria duration and severity: a systematic review. Int Arch Allergy Immunol 2013;161:197-204.

33 Cantarutti A, Donà D, Visentin F, Borgia E, Scamarcia A, Cantarutti L, Peruzzi E, Egan CG, Villa M, Giaquinto C, Pedianet: Epidemiology of frequently occurring skin diseases in Italian Children from 2006 to 2012: a retrospective, population-based study. Pediatr Dermatol 2015, Epub ahead of print. 